\title{
IMPLEMENTASI K-NEAREST NEIGHBOR PADA PENENTUAN KELUARGA MISKIN BAGI DINAS SOSIAL KABUPATEN TABANAN
}

\author{
I Wayan Supriana ${ }^{1)}$ Luh Gede Astuti ${ }^{2)}$ \\ Jurusan Ilmu Komputer, Fakultas Matematika dan Ilmu Pengetahuan Alam 1) 2) \\ Universitas Udayana, Badung, Bali. \\ wayan.supriana@unud.ac.id ${ }^{1)}$ lg.astuti@ cs.unud.ac.id²)
}

\begin{abstract}
Poverty is one of the problems prioritized for completion by the central government or the regions. This condition seems to have no limits because every year the problem of poverty is an issue that has always been a discussion of the government. As in Bali, even though the tourism industry is growing very rapidly, until now the problem of poverty is still a fundamental problem that needs to be resolved. Based on data from the Central Statistics Agency in 2016 the poverty rate of the province of Bali is $4.25 \%$ and one of the districts that has a higher poverty rate than the province is Tabanan Regency [1]. Various poverty alleviation programs have been implemented to break the cycle of poverty. However, poverty alleviation programs that have been implemented by the Tabanan regional government are still not optimal. In overcoming these problems, this study has the aim of creating an application system that can identify the conditions of households in Tabanan regency. The system built will identify a family based on 5 welfare categories so that it will provide an easy assessment for the poverty program survey officers. The system development model uses the $K$-Nearest Nighbor algorithm in modeling and classifying households. The results showed the system had an assessment accuracy rate of $83 \%$
\end{abstract}

Keywords: Poverty, Poor Households, K-Nearest Neighbor

\begin{abstract}
ABSTRAK
Kemiskinan menjadi salah satu permsalahan yang diprioritaskan untuk di selesaikan oleh pemerintah pusat maupu daerah. Kondisi ini seakan tidak ada batasnya karena setiap tahun permasalahan kemiskinan merupakan isu yang selalu menjadi pembahasan pemerintah. Seperti halnya di provinsi bali, meskipun industri pariwisata berkembang sangat pesat namu sampai saat ini permasalahan kemiskinan masih menjadi permasalahan mendasar yang perlu diselesaikan. Berdasarkan data Badan Pusat Statistik tahun 2016 tingkat kemiskinan provinsi bali sebesar 4,25\% dan salah satu kabupaten yang memiliki tingkat kemiskinan lebih tinggi dari provinsi adalah Kabupaten Tabanan [1]. Berbagai program pengentasan kemiskinan sudah dilaksanakan untuk memutus siklus kemiskinan yang terjadi. Namun program-program pengentasan kemiskinan yang sudah dilaksanakan pemerintah daerah Tabanan masih belum optimal. Dalam mengatasi permasalahan tersebut, pada penelitian ini memiliki tujuan untuk membuat sistem aplikasi yang dapat mengidentifikasi kondisi rumah tangga yang ada di kabupaten Tabanan. Sistem yang dibangun akan mengidentifikasi sebuah keluarga berdasarkan 5 katagori kesejahteraan sehingga akan memberikan kemudahan penilaian untuk petugas pendata program kemiskinan. Model pengembangan sistem menggunakan algoritma K-Nearest Nighbor dalam memodelkan dan mengklasifikasi rumah tangga. Hasil penelitian menunjukkan sistem memiliki tingkat akurasi penilaian sebesar $83 \%$

Kata Kunci : Kemiskinan, Rumah Tangga Miskin, K-Nearest Neighbor
\end{abstract}




\section{Pendahuluan}

Kemiskinan adalah suatu kondisi dimana kebutuhan pokok atau kebutuhan standar minimum tidak dapat terpenuhi dengan baik seperti makanan, pakaian, rumah, pendidikan dan kesehatan. Jumlah penduduk miskin atau penduduk dengan pengeluaran per kapita per bulan di bawah garis kemiskinan mencapai 178 ribu orang atau 4,25\% [1]. Kondisi ini cukup mengkhawatirkan di tengah industri pariwisata Bali yang maju dengan pesatnya. Seperti salah satu kabupaten dengan tingkat kemiskinan tertinggi adalah kabupaten Tabanan yaitu sebesar 5\% lebih besar apabila dibandingkan dengan kemiskinan provinsi Bali serta program-program pengentasan kemiskinan sudah dilaksanakan oleh pemerintah daerah untuk memutus rantai kemiskinan.

Pemerintah kabupaten Tabanan melalui Dinas Sosial telah melakukan usaha kegiatan untuk mengurangi jumlah penduduk miskin khususnya keluarga penyandang masalah kesejahteraan sosial (PMKS). Berbagai program yang sudah dilaksanakan seperti program pemberdayaan ekonomi melalui Bumdesa yaitu Keramba Emas (Kreatif Bersama Membangun Ekonomi masyarakat), Program Gempur Miskin, serta inovasi seperti Gerbang Pangan dan Gerbang Emas Serasi dan masih banyak program pengentasan kemiskinan yang lainnya.

Program-program pengentasan kemiskinan yang sudah dilaksanakan pemerintah daerah Tabanan masih belum optimal hal ini ini terjadi karena data yang digunakan sebagai acuan oleh pemerintah daerah adalah data kependudukan yang tidak akurat. Misalnya kasus pembagian raskin (beras untuk rumah tangga miskin) tahun 2016 yang masih menggunakan data kependudukan tahun 2015, hal ini mengakibatkan beberapa rumah tangga yang seharusnya layak untuk mendapatkan bantuan namun tidak mendapatkan bantuan, sedangkan rumah tangga yang seharusnya sudah dianggap berkembang dan tidak mendapatkan bantuan masih mendapatkan bantuan.

Berdasarkan kasus tersebut, maka dalam penelitian ini perlu dikembangkan sebuah sistem aplikasi yang dapat mengidentifikasi kondisi rumah tangga yang ada di desa. Melalui Badan Koordinasi Keluarga Bencana Nasional (BKKBN) dan sesuai dengan survei perencanaan keluarga nasional tahun 1994 yaitu penargetan keluarga miskin dibagi dalam 5 katagori kesejahteraan yaitu keluarga pra sejahtera (Pra-KS), keluarga sejahtera 1 (KS1), keluarga sejahtera 2 (KS2), keluarga sejahtera 3 (KS3) dan keluarga sejahtera 3 plus (KS3 Plus). Sistem yang dibangun akan mengidentifikasi sebuah keluarga berdasarkan 5 katagori kesejahteraan sehingga akan memberikan kemudahan penilaian untuk petugas pendata rumah tangga, selain itu data yang masuk pada sistem akan terbarui di dalam basisdata secara otomatis, sehingga pada saat pengguna mengakses aplikasi akan melihat data yang terbaru. Model pengembangan sistem menggunakan algoritma K-Nearest Neighbor dalam memodelkan dan mengklasifikasi rumah tangga.

Algoritma K-Nearest Neighbor (KNN) adalah sebuah metode klasifikasi terhadap sekumpulan data berdasarkan pembelajaran data yang sudah terklasifikasikan sebelumya [2]. Termasuk dalam supervised learning, dimana hasil query instance yang baru diklasifikasikan berdasarkan mayoritas kedekatan jarak dari kategori yang ada dalam K-NN [4]. Algoritma ini juga merupakan salah satu teknik lazy learning. K$\mathrm{NN}$ dilakukan dengan mencari kelompok $\mathrm{k}$ objek dalam data training yang paling dekat (mirip) dengan objek pada data baru atau data testing [5]. Tahapan Langkah Algoritma K$\mathrm{NN}$ (1) menentukan parameter $\mathrm{k}$ /jumlah tetangga paling dekat, (2) menghitung kuadrat jarak eucliden objek terhadap data training yang diberikan (3) mengurutkan hasil no 2 secara ascending, (4) mengumpulkan kategori Y /Klasifikasi nearest neighbor berdasarkan nilai $\mathrm{k}$ (5) dengan menggunakan kategori nearest neighbor yang paling mayoritas maka dapat dipredisikan kategori objek.

Secara umum untuk mendefinisikan jarak antara dua objek $x$ dan $y$, digunakan rumus jarak Euclidean [4].

$$
d_{x y}=\sqrt{\sum_{i=1}^{n}\left(x_{i}-y_{i}\right)^{2}}
$$

$d_{x y}$ merupakan jarak Euclidean, $x$ adalah data latih, $y$ data yang di uji, $i$ fitur ke- $i$ dan $n$ adalah jumlah fitur.

Dalam rangka mempercepat pengentasan kemiskinan di Provinsi Bali, Pemerintah daerah Provinsi Bali membuat terobosan baru dengan mengoptimalkan kinerja jajaran pemerintah Provinsi Bali melalui 
pembentukan Tim Evaluasi Pengentasan Kemiskinan Terpadu [1]. Tim ini nantinya bertugas untuk mengevaluasi program pengentasan kemiskinan secara terpadu. Hasil evaluasi memberikan rekomendasi permasalahan yang dihadapi oleh masingmasing desa untuk segera dapat dicarikan solusi dan dalam rangka perencanaan programam selanjutnya.

\section{METODE}

Teknik pendekatan pengembangan sistem menggunakan langkah seperti diuraikan pada bagian dibawah ini [3].

\section{Analisis}

Proses identifikasi tingkat kesejahteraan rumah tangga merupakan hal yang tidak mudah dan harus memperhatikan berbagai aspek dari proses identifikasi yang sifatnya valid. Luaran dari proses identifikasi kesejahteraan rumah tangga diharapkan dapat dimanfaatkan sebagai dasar penentuan tingkat kemiskinan masyarakat dengan tujuan dapat menyalurkan bantuan kemiskinan dengan tepat sasaran.
Kendala yang ditemukan dalam proses identifikasi tingkat kesejahteraan rumah tangga di Kabupaten Tabanan saat ini adalah sebagai berikut: (1) Terdapat kesulitan dalam proses penilaian tingkat kesejahteraan rumah tangga seperti standar bobot pada masingmasing indikator belum jelas, (2) Informasi data rumah tangga sebagian tersimpan secara manual dan sebagian lagi sudah terkomputerisasi tetapi belum tersimpan dalam sebuah database, hal ini menyebabkan pencarian tidak dapat dilakukan secara optimal, (3) Adanya ketidaksesuaian data rumah tangga penerima bantuan program pengentasan kemiskinan, (4) Data histori rumah tangga penerima bantuan tidak terekam dengan baik sehingga kesulitan dalam mengevaluasi masyarakat miskin.

Pengukuran tingkat kesesuai sistem atau akurasi menggunakan persamaan berikut:

Accuracy $=\frac{\text { jumlahnilaibenar }}{\text { Jumlahdatakeseluruhan }} \times 100 \%$

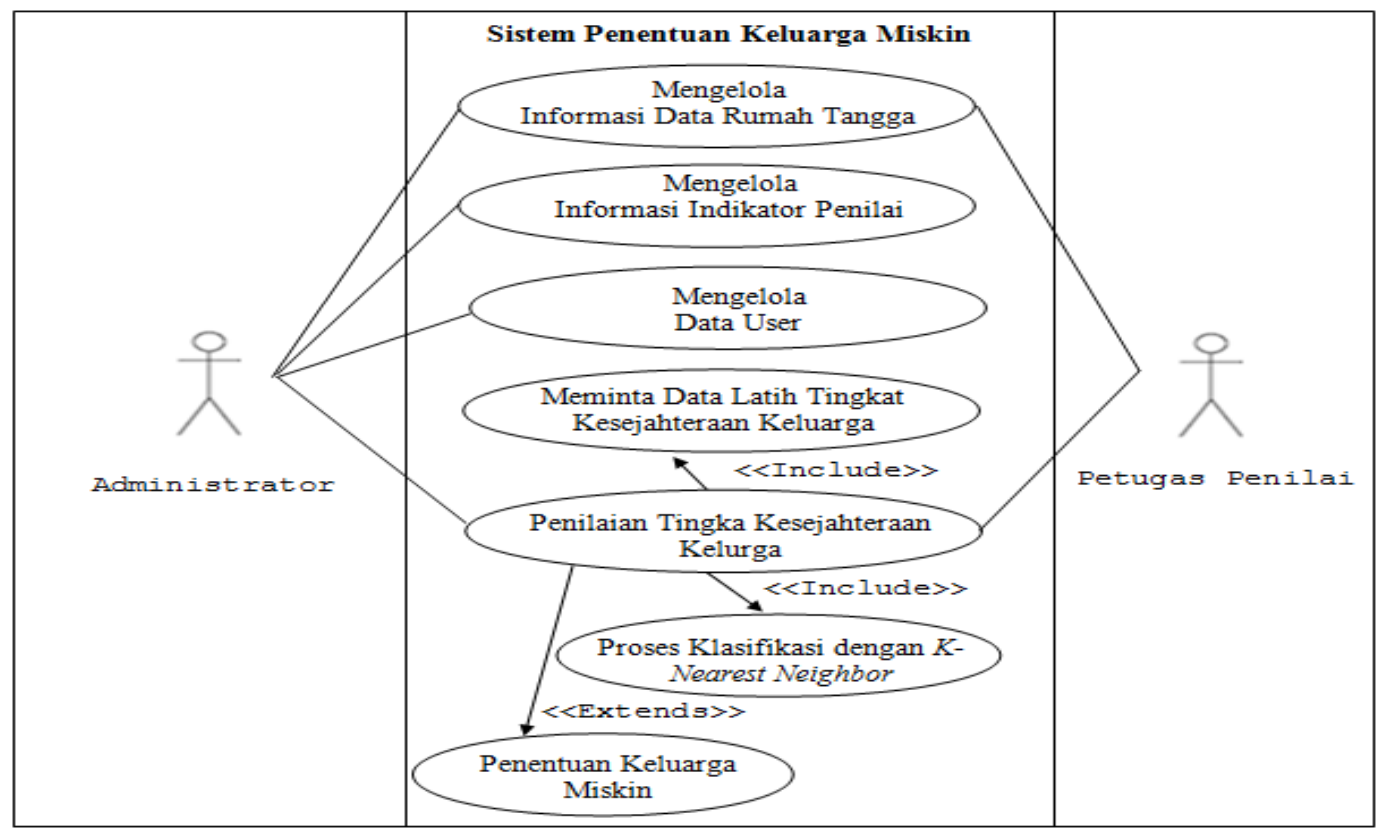

Gambar 1. Diagram Use Case Sistem

Berdasarkan kebutuhan informasi, dapat ditentukan kebutuhan fungsional yaitu menjelaskan fungsi yang dilakukan sistem dari sisi pengguna. Kebutuhan fungsional digambarkan dalam use case sistem pada gambar 1.

\section{Perancangan}

Melalui analisis sistem tahap selanjutnya adalah perancangan. Model penilaian keluarga menggunakan algoritma K-Nearest Neighbor dalam mengklasifikasi kelas kesejah-teraan keluarga. Tahapan 
klasifisikasi yang dilakukan adalah: (1) preprosesing data: Proses ini merupakan proses awal yang bertujuan untuk mempersiapkan data keluarga yang akan mengalami pengolahan pada proses selanjutnya.

Berdasarkan studi lapangan mengenai permasalahan pada proses pendataan identifikasi keluarga, maka dibutuhkan informasi sebagi berikut:

1) Informasi dalam proses penilaian secara baku sebuah keluarga untuk menentukan tingkat kesejahteraan

2) Data penilaian keluarga terdata dan tersimpan dengan baik untuk memudahkan melakukan evaluasi tingkat kesejahteraan

3) Penilaian kesejahteraan keluarga diklasifikasi menjadi keluarga pra sejahtera (KPS), keluarga sejahtera I (KS I), keluarga sejahtera II (KS II), keluarga sejahtera III (KS III), keluarga sejahtera III plus (KS III plus)

4) Terdapat pelaporan penilaian keluarga untuk menentukan tingkat kesejahteraan keluarga yaitu tergolong miskin atau tidak miskin
Pada tahap ini data disiapkan untuk menjadi data latih sistem yaitu mengidentifikasi dengan mentransformasi data ke suatu format yang prosesnya lebih mudah dan efektif. Selain itu pada tahap ini juga dilakukan penghapusan data yang berupa : gangguan (noisy) adalah kesalahan atau nilai outlier yang menyimpang dan tidak sesuai dengan data yang lain, data tidak konsisten (inconsisten) adalah ketidakcocokan dalam penggunaan data dan data tidak lengkap (incomplete) adalah kekurangan nilai-nilai pada atribut tertentu. Langkah selanjutnya dengan melakukan min-max normalization yaitu untuk melakukan preprosesing yang bertujuan untuk mendapatkan standar nilai pada semua atribut atau idikator dalam perhitungan.

Klasifikasi data: algoritma K-Nearest Neighbor melakukan klasifikasi berdasarkan pembelajaran data keluarga yang sudah terklasifikasikan sebelumya (data training). Proses pembelajaran dilakukan berdasarkan hasil query instance yang baru diklasifikasikan berdasarkan mayoritas kedekatan jarak dari kategori yang ada. Algoritma proses penilaian adalah sebagai berikut ini:

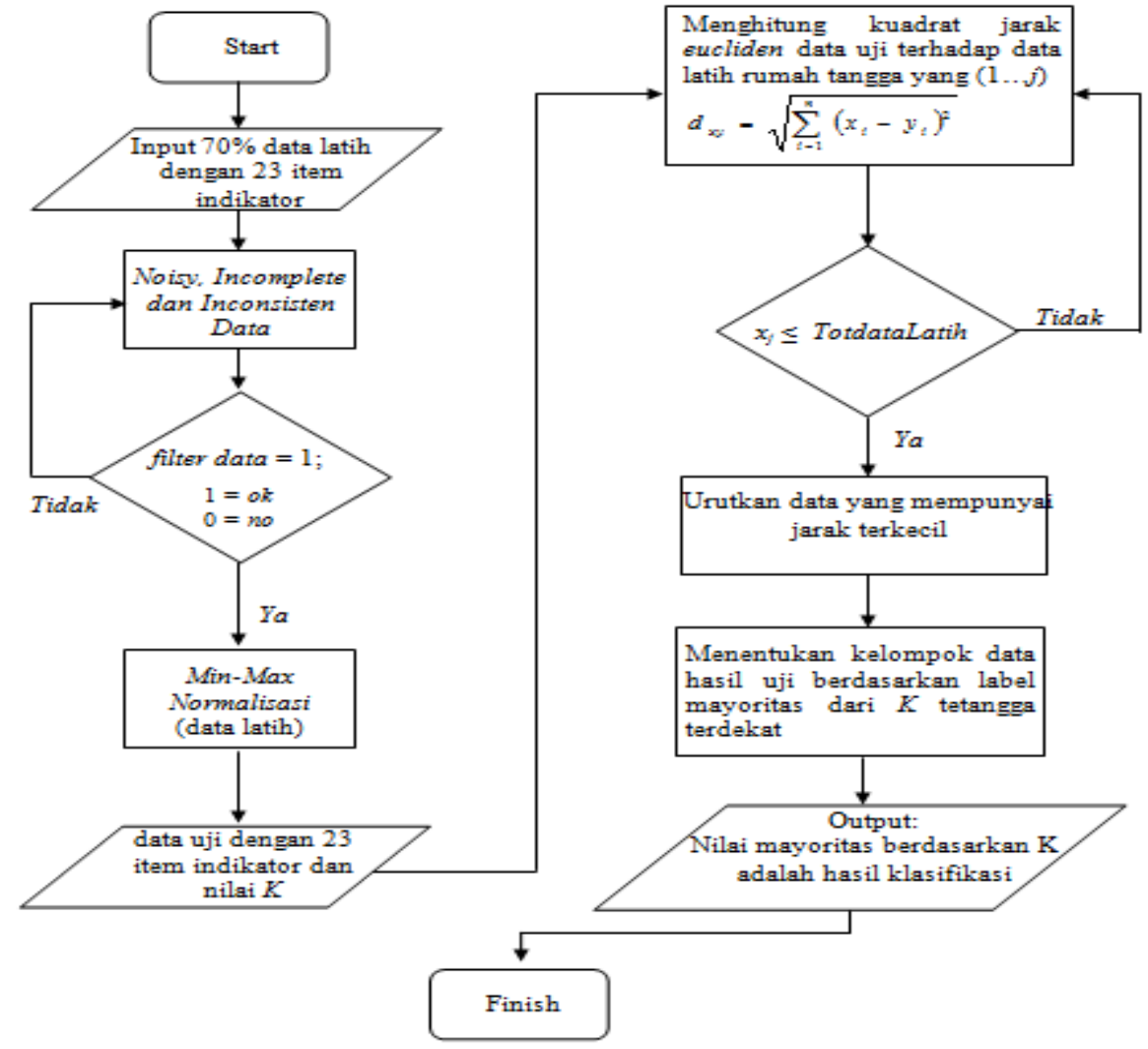

Gambar 2. Flowchat Tahapan Klasifikasi Keluaga Miskin 
1. Baca data inputan

2. Proses preprosesing data input

a. lakukan pembersihan data dari noisy, incomplete dan inconsisten

b. normalisasi proses pembersihan dengan nim-max normalisation

3. Proses klasifikasi

a. hitung jarang data uji terhadap semua data latih sistem

b. mengurutkan jarak data uji dengan data latih dari yang terkecil sampai terbesar dengan jumlah $K$ tetangga terdekat

4. Hasil klasifikasi adalah data mayoritas dengan K tetangga terdekat

5. Selesai
Analisis kebutuhan pengguna sistem menunjukkan proses pada sistem yang dikembangkan melalui perancangan sistem berupa Data Flow Diagram (DFD) Diagram konteks menggambarkan sistem dengan lingkungan luar sistem, yaitu menjelaskan kondisi sistem yang ada baik

input maupun output serta menyertakan terminator yang terlibat dalam penggunaan sistem. Terdapat dua pengguna dari sistem yang dibangun yaitu administrator dan petugas penilai. Proses berikutnya adalah DFD level 1 yaitu uraian lebih rinci dari diagram konteks.

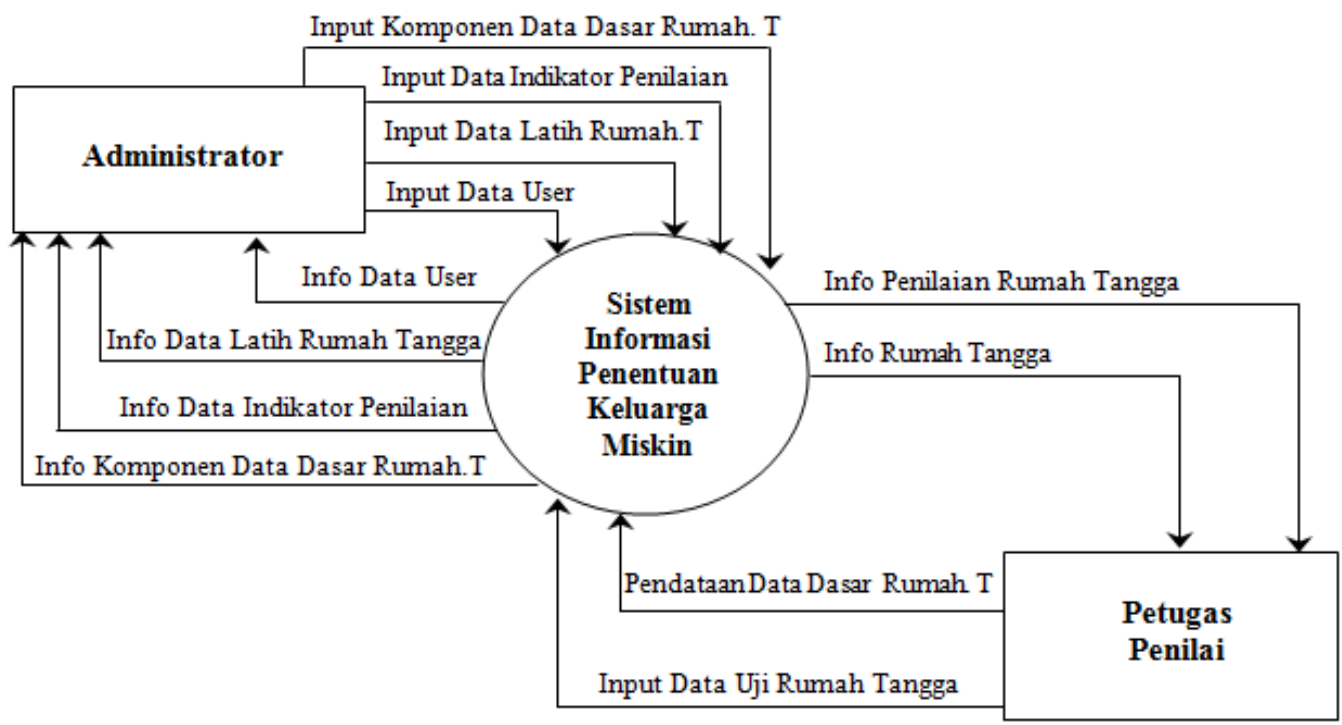

Gambar 3. Diagram Konteks Sistem 


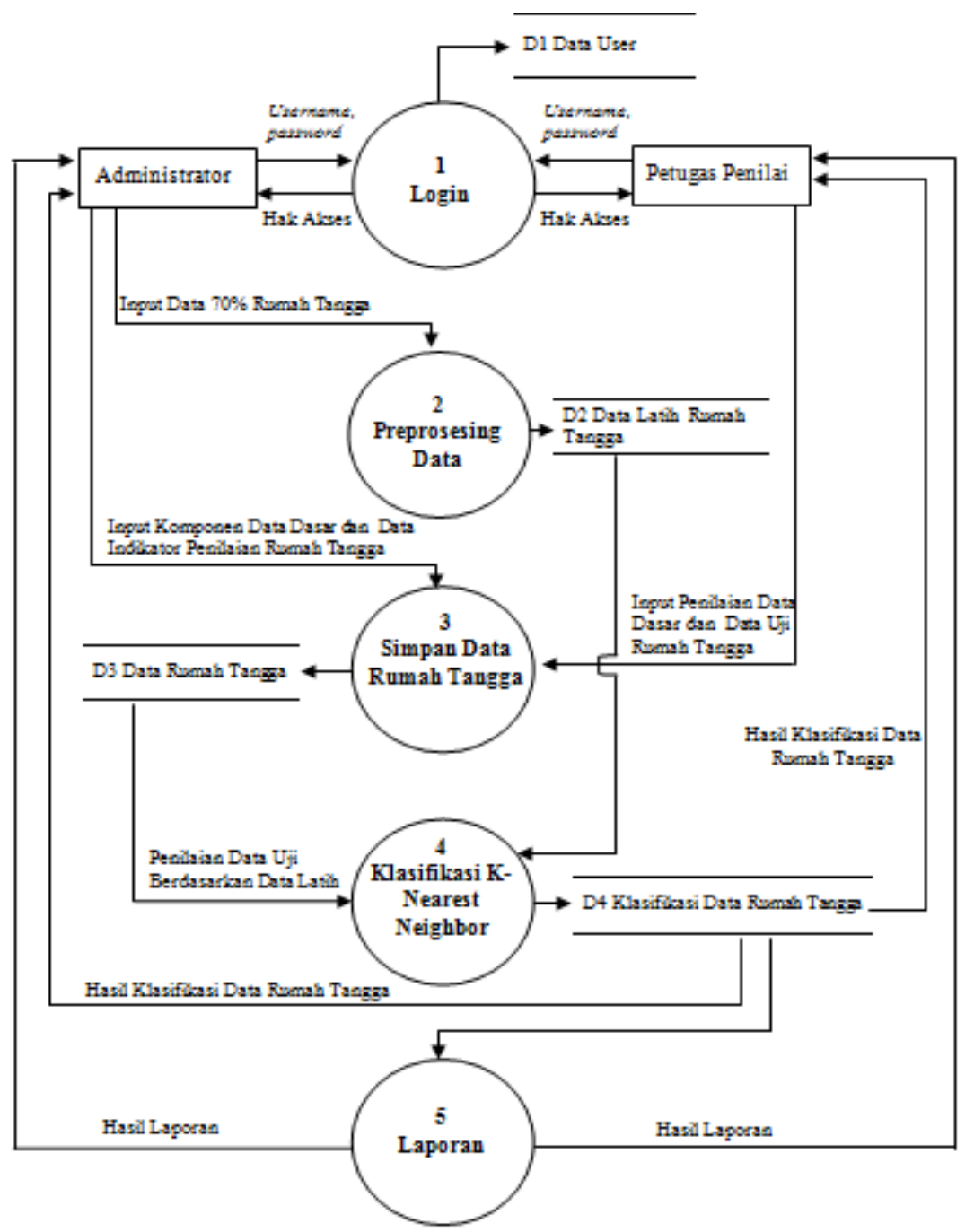

Gambar. 4 DFD Level 1 Sistem

Proses awal adalah proses login pada user pengguna yaitu administrator yang memiliki otoritas sebagai user untuk proses input komponen data dasar, komponen indikator rumah tangga, data latih sistem serta data user. Level berikutnya adalah pengguna sistem yaitu petugas penilai yang memiliki fungsionalitas untuk melakukan proses pendataan dan penilaian berdasarkan indikator sistem. Proses kedua adalah preprosesing data yaitu membersihkan data latih dari noisy, incomplete dan inconsisten serta melakukan normalisasi sehingga mudah dalam proses perhitungan dengan metode $\mathrm{K}$ Nearest
Neighbor. Proses ketiga adalah simpan data rumah tangga yaitu menyimpan komponen data dasar dan komponen indikator rumah tangga. Proses keempat adalah mengklasifikasi data uji berdasarkan data latih dengan K-Nearest Neighbor. Proses terakhir adalah membuat dalam bentuk laporan dari hasil klasifikasi atau penilaian sistem Berikutnya adalah rancangan database sistem yang disajikan dalam entity relationship diagram (ERD) menggambarkan entitas dalam sistem sebagai komponen data yang nantinya dikelola dalam sistem. 


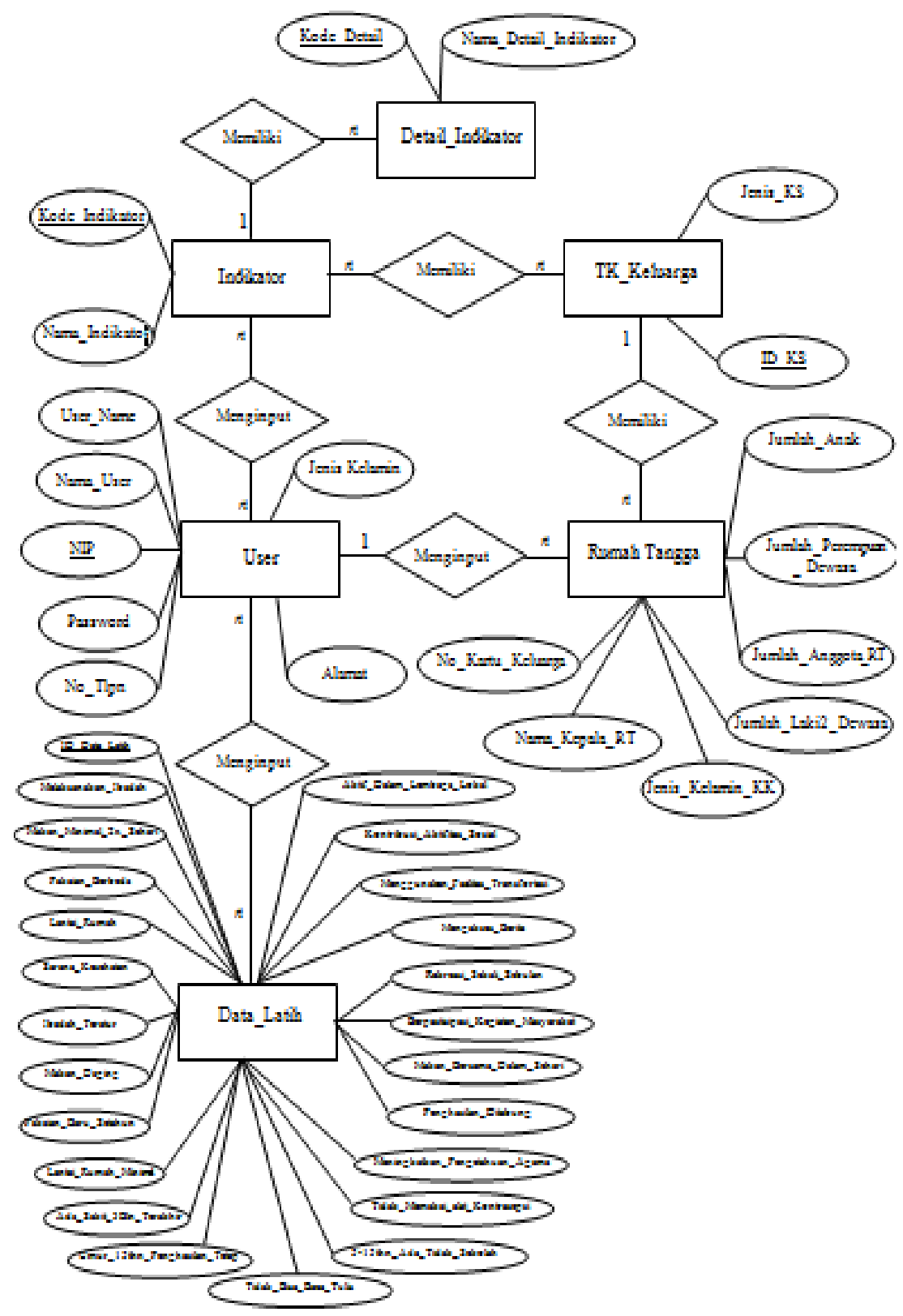

Gambar 5. Entity Relationship Diagram Sistem

\section{HASIL DAN PEMBAHASAN}

Luaran penelitian mengenai imple-mentasi K-Nearest Neighbor pada penentuan keluarga miskin bagi dinas sosial kabupaten Tabanan, yaitu implementasi dalam bahasa pemro-graman berbasis web dengan proses normalisasi data latih sebagai data pembanding pada proses penilaian dengan data uji, proses data rumah tangga yang dinilai sehingga terekam dalam sistem, proses penilaian yaitu menentukan klasifikasi rumah tangga yang dinilai tergolong miskin atau tidak. Implementasi sistem disajikan pada gambar dibawah ini 
Skenario pengujian dilakukan dengan confusion matrik digunakan untuk evaluasi model klasifikasi untuk memperkirakan obyek yang benar atau salah. Sebuah matrik dari prediksi yang akan dibandingkan dengan kelas asli dari inputan atau informasi nilai aktual dan prediksi pada klasifikasi. Data yang digunakan dalam pengujian sistem adalah data penduduk Desa Senganan, Kecamatan Penebel, Kabupaten Tabanan. Pengujian confusion matriks dengan menilai 12 data keluarga dari banjar dinas yang berbeda di Desa Senganan, dengan jumlah KNear (rangking) yang digunakan dalam sistem sebanyak 10 .
1. Rumah tangga I Gusti Ngurah Pinget dari banjar dinas Bugbugan Kelod, dengan hasil sepuluh rangking terbaik yaitu KS I sebanyak 8 item dengan ratarata jarak pada data latih sebesar 2,48 dan KS III sebanyak 2 item dengan ratarata jarak pada data latih sebesar 2,84. Sehingga pada proses penilaian dengan sistem dapat dinyatakan keluarga ini termasuk Keluarga Sejahtera I.

2. Rumah tangga I Made Darma Yasa dari banjar dinas Soka Kangin, dengan hasil sepuluh rangking terbaik yaitu seluruhnya KS II dengan rata-rata jarak pada data latih sebesar 0.47. Sehingga pada proses penilaian sistem dapat dinyatakan keluarga ini termasuk Keluarga Sejahtera II.
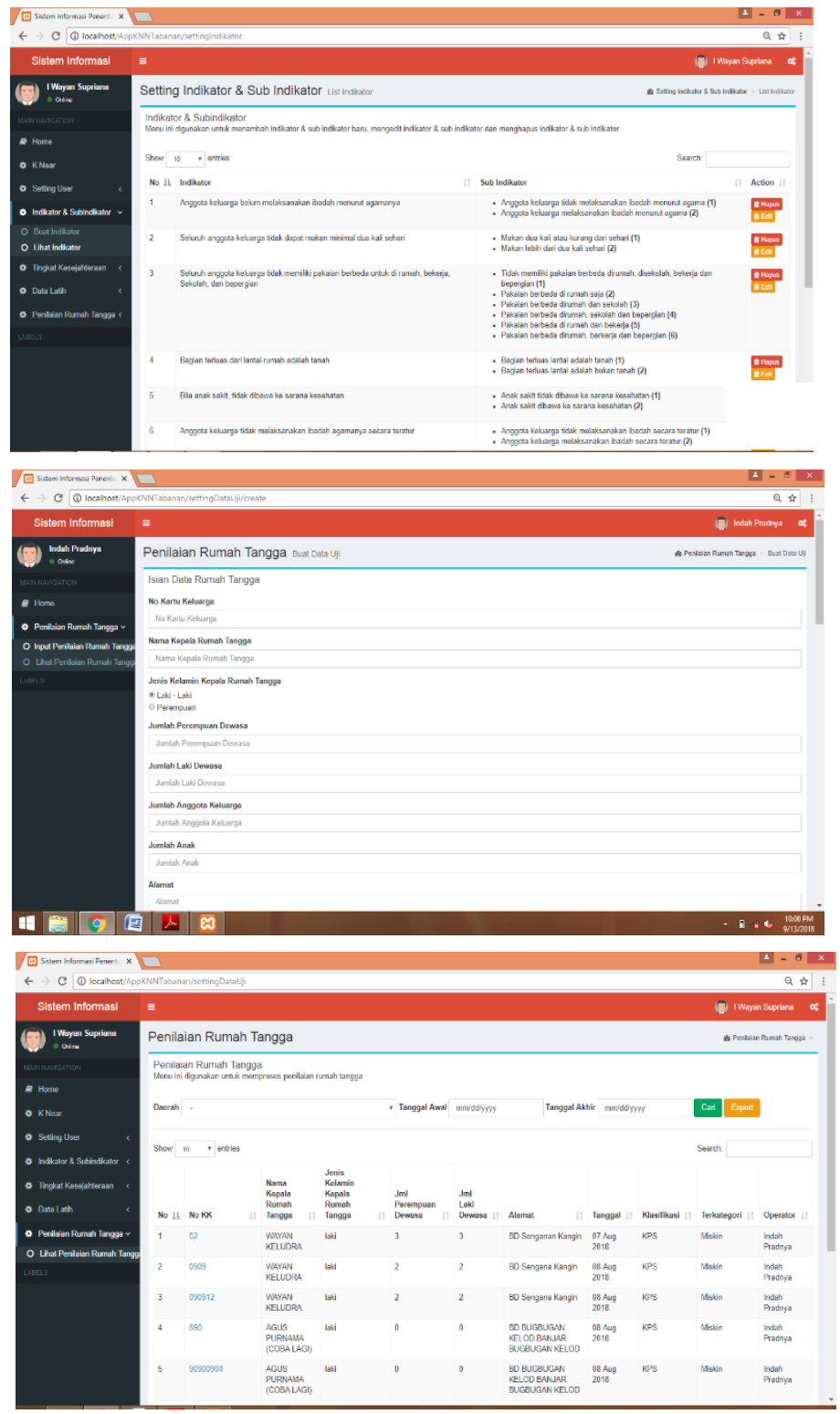

Gambar 6. Implementasi Sistem Penilaian Keluarga Miskin 
3. Rumah tangga I Wayan Sepi Arsana dari banjar dinas Keridan, dengan hasil sepuluh rangking terbaik yaitu KS III Plus sebanyak 9 item dengan rata-rata jarak pada data latih sebesar 0,82 dan KS III sebanyak 1 item dengan rata-rata jarak pada data latih sebesar 1,58. Sehingga pada proses penilaian sistem dapat dinyatakan keluarga ini termasuk Keluarga Sejahtera III Plus

4. Rumah tangga I Made Kerta Yasa dari banjar dinas Senganan Kangin, dengan hasil sepuluh rangking terbaik yaitu seluruhnya KS III dengan rata-rata jarak pada data latih sebesar 1.57. Sehingga pada proses penilaian sistem dapat dinyatakan keluarga ini termasuk Keluarga Sejahtera III.

5. Rumah tangga I Made Patra dari banjar dinas Pagi, dengan hasil sepuluh rangking terbaik yaitu seluruhnya KPS dengan rata-rata jarak pada data latih sebesar 0.14. Sehingga pada proses penilaian sistem dapat dinyatakan keluarga ini termasuk Keluarga Pra Sejahtera.

6. Rumah tangga I Gusti Ngurah Jerman dari banjar dinas Bugbugan Sari, dengan hasil sepuluh ranging terbaik yaitu seluruhnya KS II dengan rata-rata jarak pada data latih sebesar 1.26. Sehingga pada proses penilaian sistem dapat dinyatakan keluarga ini termasuk Keluarga Sejahtera II.
7. Rumah tangga I Ketut Sukayasa dari banjar dinas Belatung, dengan hasil sepuluh rangking terbaik yaitu seluruhnya KPS dengan rata-rata jarak pada data latih sebesar 0.73. Sehingga pada proses penilaian sistem dapat dinyatakan keluarga ini termasuk Keluarga Pra Sejahtera.

8. Rumah tangga I Gusti Nyoman Budi Artawan dari banjar dinas Senganan Kangin, dengan hasil sepuluh rangking terbaik yaitu seluruhnya KS I dengan rata-rata jarak pada data latih sebesar 1.88. Sehingga pada proses penilaian sistem dapat dinyatakan keluarga ini termasuk Keluarga Sejahtera I.

9. Rumah tangga I Gusti Putu Selat dari banjar dinas Senganan Kangin, dengan hasil sepuluh rangking terbaik yaitu seluruhnya KS III dengan rata-rata jarak pada data latih sebesar 1.31. Sehingga pada proses penilaian sistem dapat dinyatakan keluarga ini termasuk Keluarga Sejahtera III.

10. Rumah tangga I Wayan Sukabrata dari banjar dinas Soka Kawan, dengan hasil sepuluh rangking terbaik yaitu seluruhnya KS II dengan rata-rata jarak pada data latih sebesar 0.42 . Sehingga pada proses penilaian sistem dapat dinyatakan keluarga ini termasuk Keluarga Sejahtera II.

11. Rumah tangga I Gusti Ngurah Mawar dari banjar dinas Bugbugan Kelod, dengan hasil sepuluh rangking terbaik yaitu seluruhnya KS III dengan rata-rata jarak pada data latih sebesar 1.20 . Sehingga pada proses penilaian sistem dapat dinyatakan keluarga ini termasuk Keluarga Sejahtera III.

Tabel 1. Data Penilaian Keluarga Dinas Sosial Kabupaten Tabanan

\begin{tabular}{|l|l|l|c|}
\hline No & \multicolumn{1}{|c|}{$\begin{array}{c}\text { Nama Kepala } \\
\text { Rumah Tangga }\end{array}$} & \multicolumn{1}{|c|}{ Alamat } & $\begin{array}{c}\text { Tingkat Kesejahteraan } \\
\text { Rumah Tangga }\end{array}$ \\
\hline 1 & I Gusti Ngurah Pinget & Banjar Dinas Bugbugan Kelod & KS I \\
\hline 2 & I Made Darma Yasa & Banjar Dinas Soka Kangin & KS II \\
\hline 3 & I Wayan Sepi Arsana & Banjar Dinas Keridan & KS III Plus \\
\hline 4 & I Made Kerta Yasa & Banjar Dinas Senganan Kangin & KS III \\
\hline 5 & I Made Patra & Banjar Dinas Pagi & KPS \\
\hline 6 & I Gusti Ngurah Jerman & Banjar Dinas Bugbugan Sari & KS I \\
\hline 7 & I Ketut Sukayasa & Banjar Dinas Belatung & KPS \\
\hline 8 & $\begin{array}{l}\text { I Gusti Nyoman Budi } \\
\text { Artawan }\end{array}$ & Banjar Dinas Senganan Kangin & KS III \\
\hline 9 & I Gusti Putu Selat & Banjar Dinas Senganan Kangin & KS II \\
\hline 10 & I Wayan Sukabrata & Banjar Dinas Soka Kawan & KS III \\
\hline 11 & I Gusti Ngurah Mawar & Banjar Dinas Bugbugan Kelod & KSP \\
\hline 12 & I Ketut Kisid & Banjar Dinas Pacung & \\
\hline
\end{tabular}


12. Rumah tangga I Ketut Kisid dari banjar dinas Pacung, dengan hasil sepuluh rangking terbaik yaitu KPS sebanyak 5 item dengan rata-rata jarak pada data latih sebesar 1,40 dan KS I sebanyak 5 item dengan rata-rata jarak pada data latih sebesar 1,41. Sehingga pada proses penilaian dengan sistem dapat dinyatakan keluarga ini termasuk Keluarga Pra Sejahtera.

Sementara untuk penilaian manual yang sudah dilakukan oleh Dinas Sosial Kabupaten Tabanan menghasilkan data seperti tabel 1 .

Melalui hasil penilaian sistem apabila disandingkan dengan data penilaian Dinsos (Dinas Sosial Tabanan) dengan data yang sama dengan data uji sistem, penilaian mendekati mendekati proses penilaian manual. Pada pengujian 12 data di identifikasi dan di klasifikasi oleh sistem dengan 2 perbedaan klasifikasi jika dibandingkan dengan proses penilaian manual dari data Dinas Sosial Kabupaten Tabanan. Akurasi yang dihasilkan oleh sistem dapat dihitung sebagai berikut.

Persentase Akurasi $=\frac{10}{12} \times 100 \%=83,33 \%$

Hasil akurasi dari pengujian sistem diperoleh sebesar $83 \%$ sistem mampu mengidentifikasi dengan benar tingkat kesejahteraan rumah tangga

\section{SIMPULAN}

Analisis serta perancangan sistem penentuan keluarga miskin dapat dilakukan pengembangan aplikasinya melalui faktor keluarga miskin di Kabupaten Tabanan Metode K-Nearest Neighbor dapat diimplementasikan serta dapat mengklasifikasi tingkat kesejahteraan rumah tangga dengan akurasi sebesar $83 \%$

\section{DAFTAR PUSTAKA}

[1] Badan Pusat Statistik Bali, 2016. Sekretariat Komite Penanggulangan Kemiskinan Republik Indonesia. Denpasar

[2] Nugraha, D.W, Putri, R.R.M dan Wihandika, R.C, 2017. "Penerapan Fuzzy K-Nearest Neighbor (FK-NN) Dalam Menentukan Status Gizi Balita". Jurnal Pengembangan Teknologi Informasi dan Ilmu Komputer, Vol.1, No.9, 2017

[3] Kendall, K.E. dan Kendall, J.E. 2006. Analisis dan Perancangan Sistem Informasi. Versi Bahasa Indonesia. Edisi Kelima. Jilid I. PT. Indeks Kelompok Gramedia. Jakarta.

[4] Jayanti, R.D. “Aplikasi Metode K-Nearest Neighbor Dan Analisa Diskriminan Untuk Analisa Resiko Kredit Pada Koperasi Simpan Pinjam Di Kopinkra Sumber Rejeki". Prosiding Seminar Nasional Aplikasi Sains dan Teknologi (SNAST). Yogyakarta. 2014.

[5] Leidiyana. "Penerapan Algoritma $K$ Nearest Neighbor Untuk Penentuan Resiko Kredit Kepemilikan Kendaraan Bemotor". Jurnal Penelitian Ilmu Komputer, System Embedded \& Logic, Vol : 1. STMIK Nusa Mandiri. 2010. 